Jolanta Walas-Trębacz ${ }^{1}$

The Cracow University of Economics,

Department of Management Process
ORIGINAL SCIENTIFIC ARTICLE doi:10.5937/ekonomika1802009W

Received January, 24, 2018

Accepted: March, 01, 2018

\title{
EFFICIENCY EVALUATION OF THE FUNCTIONING OF AN ENTERPRISE'S VALUE CHAIN AS A CRITERION FOR THE CHOICE OF A SUCCESSFUL STRATEGY OF MARKET COMPETITION
}

\begin{abstract}
Nowadays, an important issue, taken up by both researchers and practitioners in the field of business management, is to find whether an applied method of value creation produces the anticipated effects (value added), not only from the perspective of the enterprise itself, but most of all, from the point of view of the ultimate customer. The aim of this article, on the basis of a profound analysis of literature on the subject being conducted, is to present an interpretation of the term of efficiency, which is explained differently and examined in relation to the given perspective (area of science). Moreover, in the article, there is an interpretation of the term of an efficient value chain of an enterprise given; in addition to that, various types of applicable approaches to the efficiency evaluation of a value chain of a business are presented, in a synthetic manner. Apart from showing several approaches, different criteria, which can be used while making an appraisal of efficiency of a value chain at different levels, were also depicted. This topic was taken up by the Author, taking into consideration the growing importance, which business managers attach to the implementation of measurement and assessment of efficiency of a value chain. It is an important problem from the perspective of selection or preparation of a successful model, allowing for a multidimensional evaluation of efficiency of management of the existing value chain of an enterprise, as well as the decision-making associated with the choice of a type of strategy, which would result in a company gaining or maintaining the competitive advantage in the market.
\end{abstract}

Key words: efficiency, value chain, efficient value chain of an enterprise, efficiency evaluation of a value chain, criterion of evaluation

JEL classification: $L 1, L 6, M 2$

\section{ЕВАЛУАЦИЈА ЕФИКАСНОСТИ ФУНКЦИОНИСАҢА ЛАНЦА ВРЕДНОСТИ ПРЕДУЗЕһА КАО КРИТЕРИЈУМ ЗА ИЗБОР УСПЕШНЕ ТРЖИШНЕ СТРАТЕГИЈЕ}

\section{Апстракт}

Значајно питање које су данас покренули истраживачи и практичари у области управљања пословањем је да ли примењена метода стварања

${ }_{1}$ walasj@uek.krakow.pl 
вредности производа даје предвидљиве ефекте (додатну вредност), не само из перспективе самог предузећа, већ и, пре свега, са гледишта крајњег купца. Циљ овог рада је да, позивајући се на анализу постојеће литературе о предмету рада који желимо да објаснимо, представи интерпретацију појма ефикасностикојасеобјашњаваиистражујеуоквирупосматранеперспективе (области науке). Штавише, у раду је представљена интерпретација појма ефикасаности ланач вредности предузећа. Поред тога, представљени су и различити типови применљивих приступа евалуаџије ефикасности пословног ланца вредности на систематичан начин. Поред тога, приказани су и различити критеријуми који за оцеґивање ефикасности ланца вредности на различитим нивоима. Ову тему смо покренули, узимајући у обзир све већи значај који менаиери дају имплементацији мерењ а и очеґивања ефикасности ланиа вредности. Ово је важан проблем из перспективе избора или припреме успешног модела, који обезбеђује вишедимензионалну процену ефикасности управљања постојећим ланием вредности предузећа, као и одлучивање које се тиче одабира врсте стратегије, ито омогућава да компанија стекне или одржи конкурентску предност на тржишту.

Кључне речи: ефикасност, ланаи вредности, ефикасан ланаи вредности предузећа, евалуација ефикасности ланца вредности, критеријум евалуације.

\section{Introduction}

Transformations of the enterprise's management systems, which took place at the end of the 20th century, have emphasized the category of an enterprise's value as, on one hand, a basis for determining its fundamental financial objective, while on the other hand, as a measure of management's effectiveness and a tool for improvement of strategic management (Romanowska, 2001). Value management comprises such decision-making in different areas of an enterprise (investment, marketing, production, finance, services, customer service etc.), so that its value is increased within a potentially acceptable time interval (Jabłoński \&Jabłoński, 2006). Maximization of an enterprise's value requires specific management from executives, where the undertaken actions are concentrated on key factors of value creation, as these allow for integration and streamlining of the strategic and operational decision-making process (Janasz, 2003). In the literature on the subject, there is a multitude of approaches towards the description of the value creation process, conducted by an enterprise. One of the most interesting proposals was presented by C. Stabell and O. Fjeldted. Relying on the J. Thompson's typology (1976), these authors distinguish three basic configurations of value creation systems: value chains, value shop and value network (Stabell \& Fjeldstad, 1998). In the undermentioned study, the attention will be focused on the evaluation of efficiency of the value creation of an enterprise, with the use of a value chain. The concept of a value chain implies that the source of an enterprise's competitive advantage is a disaggregation of a value creation process into several separate areas of activity (chain links) - fundamental and supportive - where each of them has an influence on the cost position of a company and may form the basis for the diversification from the competitors. An essential assumption of this 
approach is that the separated links have different economics and contribute to the growth of the product's value from the client's perspective in a different manner (Porter, 1992).

\section{An interpretation of the term of efficiency in different sciences versus the efficiency of an enterprise's value chain}

Nowadays, the most important area of the quest for values is associated with the processes functioning within the enterprises, the so-called value chain (Matwiejczuk, 2010). An increase in the company's value is possible thanks to the undertakings aimed at formation and perfecting of the structure of the value chain (Cholewicka-Goździk, 2001, p. 15). A value chain constitutes the most important tool of the diagnostic tests and is an expression of a currently preferred process approach, which displays an analysis of organizational course, optimization of the manufacturing cycle and "learning" the organization (Stabryła, 2007).

Value creation can be looked into from the point of view of a chain in its entirety, meaning the value system (which includes value chains of consecutive participating subjects) or from the perspective of a chain of a singular enterprise (constituting a link of the value system). That is why, one can mention two types of chains: internal and external.

The Author defines an enterprise's value chain as a system of fundamental, supportive and managerial processes, coordinated in a manner enabling the effective creation of value added, with the participation of all parties, especially the participation of the ultimate customer in the process of product and/or service creation.

During the creation of its value chain, an enterprise can choose from the two of its types, namely the lean chain or the agile chain. The choice of the kind of the chain depends, among other things, on the sector where the company operates, the type of the manufactured product, as well as the quantity of demand and supply in the market. A sort of the internal structure of a value chain would be determined by the applied business model, by the chosen type of strategy for the enterprise's value chain and also by the kind of used concepts and methods for chain management. That is the reason why it is crucial to arrange the type of dimensions and the proper set of criteria, allowing for the evaluation of the efficiency of an enterprise's value chain functioning.

The term of efficiency can be explained with the use of different perspectives (sciences), namely making reference to: the undertakings accomplished by man (praxeology) (Kotarbiński, 1982), as well as from the perspective of: economics (both microeconomics and macroeconomics), technology, processes, ergonomics (health), sociology, etc. (Woźniak, 2012).

1. The term of efficiency with regard to the man's undertakings (Hendzel, 1998; Cabała, 2007; Szafrański, 2003) is then specified as "an ability to perform certain tasks" and refers both to the body and the mind. Efficiency concerns any man's undertakings, regardless of its reason or objective (Machnik, 2002; Łasiński, 2003; Panfil, 2006).

2. The microeconomic approach of actions' efficiency is characterized by a partial analysis of the fundamental characteristics, impacting the efficiency 
of functioning of the entire organizations (enterprises). Within the framework of the assessment of the work outlay and the achieved results, it refers almost solely to the components of activities, which can be presented in the form of financial measures, expressed in monetary units. The basic indicators applied in this approach are the economic effectiveness of activity, productivity of work and work factors (human and material resources), work output, production capability (Woźniak, 2012).

3. The macroeconomic approach refers to the measures of the efficiency of the whole country's economy, meaning all enterprises and the employed citizens. Among the exemplary measures applied in the macroeconomic comparisons of the economies of different countries, one can mention the GDP, debt levels, aggregate measures of economic development, inflation indices, levels of interest rates, etc.

4. The notion of efficiency is commonly applied in the technical science, where it means a feature of the objects' functioning. In technology, efficiency is recognized as a level, determining to what extent a device converts the energy of one form into another (e.g. electric energy into kinetic energy - a machine's motion) (Woźniak, 2012).

5. Another approach to the term of efficiency, so called process approach, is associated with the entire set of activities, most often accomplished by various executors. In the majority of organizations, the final effects of processes matter, whereas the effectiveness of consecutive elements belonging to the analyzed process remains unknown. Cases, when a product is created as a result of one-stage process - one activity, are very rare (Grajewski, 2007). Within the process approach, the following measures of efficiency are identified most frequently: an indicator of transitory efficacy, an indicator of efficacy measured in the course of production, as well as a standardized indicator of work output.

6. In the ergonomic (health) approach towards efficiency, the attention is paid to the functional dimension of health, in other words, to the condition of an individual without any disability, enabling the every-day active participation in the professional career (Chuengsatiansup, 2003).

7. Another, sociological approach towards efficiency, most often applies to the results of activities, undertaken by large groups of people (on the scale of the country, region or organization). Sociology is a science, studying the functioning and directions of changes within societies or large groups of people, in a systematic and orderly way. In general, social rules, processes and structures, together with their influence on the efficiency of individuals and the entire social organisms, are subject to the sociological study (Woźniak, 2012).

Within this study, efficiency is an issue considered from the perspective of the organization's functioning. Modern enterprises, in order to be successful in the changeable and complex environment, need to be marked by high efficiency. Their activity cannot be analyzed taking into account only the revenues and costs. The level of accomplishment of their objectives constitutes a result of managers' undertakings, within the area of exploitation of the held resources, adherence to the binding procedures, 
structuring the relations, not only between the consecutive elements of the organization, but also between the environment participants and the organization itself. The activity of an organization and its results is not of utmost importance only to owners, shareholders or stakeholders. There are also others interested in this sphere - participants of both the closer (clients, competitors, suppliers) and the more distant environment (e.g. the local community, local government etc.) (Mazurkiewicz, 2011).

The interpretations referring to the efficiency, which were presented above, will not exhaust all the problems included within the area of these issues. However, they constitute a sufficient basis for further consideration within the framework of the efficiency assessment of the functioning of an enterprise's value chain. Therefore, the Author perceives an efficient value chain of an enterprise as a successful and effective accomplishment of the prescribed objectives, stemming from the applied strategy, but also as an optimal adjustment and exploitation of resources and competences, in the consecutive fundamental and supportive processes, influencing the value creation of a product, satisfying the needs of the ultimate customer.

\section{Types of approaches used for the efficiency evaluation of an enterprise's value chain}

An issue of the efficiency evaluation of an enterprise's value chain functioning is essential from the strategic and operational point of view. This efficiency assessment is not only in the diagnostic character; it can be equally well applied within the proposals for the specification of changes improving the existing structure of a value chain or within the suggestions about the new - more dynamic or more efficient - value chains for a given enterprise.

The efficiency evaluation of an enterprise's value chain functioning may be conducted with the use of various approaches from the area of organization and management, together with the measures applied for the assessment, namely the approaches such as: an objective approach, a systemic approach, an economic approach, a stakeholders' groups approach, a process approach, a resource approach, a subjectiverelational approach, a managerial approach, etc. (Skurzyńska-Sikora, 2009; Malik, 2004; Bielski, 2002). Below, one can find a synthetic characterization of the previously mentioned approaches, applied with reference to the efficiency evaluation of an enterprise's value chain functioning.

An objective approach implies that the organizations function in order to achieve specific objectives, therefore an efficiency assessment should involve a specification of the degree of objectives' accomplishment, as well as the degree of the held resources' exploitation. A condition for high efficiency becomes associated with: a precise definition of objectives, a specification of the time period necessary for their accomplishment and measures allowing to assess this accomplishment process (Ziębicki, 2014). It means that the objectives need to be quantified, which, in case of the enterprises, triggers the aspiration for their maximization, understood as an accomplishment of an objective, in its possibly widest quality dimension (Lange, 1978). According to the definition by A. Stabryła, effectiveness is a measure of conformity of a model value (planning, prescribed 
one) to the actual state (real). Such a measure points to the degree of conformity in the objective's accomplishment (Stabryła, 2006).

A concept of stakeholders'groups constitutes an attempt to consider the organization's goals from a broader perspective, yet, it takes into account the results of current functioning as well. Within this approach, efficiency is a complex notion and should be assessed pursuant to the criteria and indicators, formulated by different groups of an organization's stakeholders (Henri, 2004). An essential assumption says that an organization cannot exist and function without the support from various groups of stakeholders, especially shareholders, employees, clients, suppliers, government, local community or society as a whole (Bratnicki \& Kulikowska-Pawlak, 2013). This is the reason why within the multiple-choice approach, effectiveness is defined as "a degree to which an organization meets the expectations of both internal and external groups of stakeholders" (Freeman, 1984; Rollinson, 2002). J. Lichtarski (1999), M. Romanowska (2002) claim that an organization's perception of the importance of both stakeholders and of maintenance of positive relations with them, is decisive for the success of such an organization and its high effectiveness.

Within the systemic approach, it is assumed that an organization is a whole and its efficient functioning depends on technical, as well as economic, sociological and psychological factors (Kieżun, 1997). The efficiency evaluation of an organization refers to its ability to survive and develop. This ability depends on the strength and cohesiveness of an organization, its position in the environment and the capability for its further reinforcement, whereas the main source of effectiveness is connected with acquiring and using the rare and valuable resources, necessary for the company to function and build relations with the environment (Yuchtman, \& Seashore, 1967). According to the systemic approach towards organization, an emphasis can be put either on entrance or exit from the system. That is why the main aspects of efficiency comprise the organization's capability for the acquisition of resources necessary for its functioning and development, an efficient transformation of these resources and also transactions within the environment (Bielski, 1996). The systemic approach, being a comprehensive perspective with regard to an enterprise's value chain (as a system of interconnected processes) will be clarified by means of integrating several approaches: economic, resource, process, subjective-relational (behavioral) and managerial one (Kieżun, 1997).

An economic approach perceives efficiency in terms of effectiveness, meaning the relation between the results and outlays, described by measures such as productivity or profitability ${ }^{7}$. Within this approach, efficiency of a perfect economic system of free competition is present, when there is an equilibrium between demand and supply. Such an equilibrium ensures the exploitation of all resources (Samuelson \& Nordhaus, 1995). The main objective of this approach is an accomplishment of a specific effect, with the use of possibly the smallest amount of available resources or an accomplishment of possibly the best result, with the use of a specific amount of resources. However, in the literature on the subject, the need for an extension of the term of effectiveness in the economic perspective is quite strongly emphasized (Martyniak, 2000), who is an opponent of limiting the effectiveness solely to this category. A similar opinion is presented by: M. Holstein-Beck (1987), M. Bielski (1996) and E. Skrzypek (2000). The basic indicators applied within this perspective include the economic effectiveness of activity, productivity of work and its factors, work output and production capability. An aggregated view of the efficiency of activity, referring to the entire organization and all of its employees, is expressed by means 
of appraisal indicators of a company's financial condition (Sierpińska \& Jachna, 2004).

In the resource approach, it is assumed that organizations need to act in a manner, enabling the best protection and application of the held, limited or particularly valuable resources. The effectiveness of resources' management by an enterprise refers to the entire property of an entity (fixed and current assets) and its employees (Duraj, 2004). It is determined by the degree of coordination of activities and derives from the applied methods of prioritization thereof (Al-jibouri, 2002). An organization should maximize its bargaining position in relation to the environment, in order to receive an optimal amount of rare and necessary resources (Crook et al., 2008). Such an understanding of effectiveness is concentrated on the ability to acquire resources from the environment and the degree of their exploitation (Greve, 2011). An issue, which is of crucial importance for an enterprise, is to build a value chain, basing on the necessary and most valuable resources. However, this does not imply that these need to be available only within the framework of this particular entity. The level of resources of an organization, together with the ability of acquiring them and the ways of using them, determines the development (a potential) of an enterprise's value chain.

A process approach towards organizations' management is based on the assumption that the main interests of an enterprise concern the economic processes and their results, as well as the coordination and integration of activity (Nowosielski, 2011). The wellprospering business processes are recognized as critical resources of a company, deciding about its market value (Seethamraju, 2013). Therefore, an accomplishment of processes, which influence the value added, is the prime mover, having impact on the organization's efficiency and in consequence, on its final results. Application of the process approach may ensure the necessary level of company's flexibility and, at the same time, enable the efficient functioning, given the circumstances of high competitiveness (Nowosielski, 2008). The main focus in this sphere is associated with the proper management of all types of processes, impacting the creation of a product's value for the ultimate customer. While evaluating the efficiency of an enterprise's value chain, it is imperative to assess, with the use of different quantitative and qualitative criteria, the efficiency of accomplishment of consecutive fundamental processes, as well as the supportive-managerial processes, which are present or purchased from the outside for an enterprise.

A subjective-relational approach allows for measurement and evaluation of a value chain, with regard to its structure, specified by the subjective dimension (number of participants), but also for measurement and assessment of the existing relations by means of two aspects: static (type of organizational and legal contracts and the scope of its application) as well as dynamic (functional - influence of relations on the undertaken processes and the scope of their changes) (Bartusik \& Sołtysik, 2015). This dynamic perspective on a value chain refers to relations, which comprise the connections visible within the dimensions of subjects, processes and resources. This concerns such interactions between subjects, where one can observe an information, material or energetic exchange, with the parties of the exchange being mutually engaged in the process. The efficiency of relations within the enterprise's value chain can be examined within the dimension of its internal or external structure. This importance of relations with different subjects is emphasized by J. Lichtarski (1999), P. Dwojacki, Cz. Sikorski, B. Nogalski (1999), S. Sudoł (2002), M. Romanowska (2002). The adoption of the clientele's orientation by modern enterprises, together with the inherent aspiration for the increase of the customers' 
satisfaction, reinforces the cooperation with the consumer and also with other subjects, determining the flexible and effective value creation of a product (Potoczek, 2010).

A crucial role within the course of measurement and evaluation of an enterprise's value chain is played by the management process, meaning the managerial approach (Blaik, 2002). A classical perspective on the management process comprises its four fundamental functions: planning, organizing, motivating and controlling. Therefore, within this approach, a great importance is associated with the assessment of the degree of accomplishment of consecutive management functions, but also with the selection and evaluation of the effectiveness of instruments applied for the value chain management. From the point of view of efficiency of an enterprise's value chain, special attention should be paid to the degree of strategic and operational management thereof, which is connected with the efficiency of both management and executive systems. In order to enhance the efficiency of an enterprise's value chain, it is also essential to constantly improve the consecutive elements and relations between them (Wysokińska-Senkus, 2013). Among the key undertakings of the management process, which can also impact the level of efficiency of an enterprise's value chain, one can enumerate: innovations and changes management, projects management, knowledge management, information management, competences management, corporate culture management, marketing management, technology management, finance management, risk management, strategic management, relations management, leadership, cooperation, communication, time and space management, etc.

\section{Criteria applied for an efficiency evaluation of an enterprise's value chain}

Efficiency of an organization's functioning, especially in the conditions of new economy, is determined by the competition, growth of the clientele's expectations in many areas (including the quality), fast changes in the sphere of technology, production and services' provision, but also by the broad transformations within the scope of organizations' activity in the market (Barczak, 2016). Organizations search then for the best management concepts, methods and techniques, which could contribute to the improvement of their functioning's efficiency.

Table 1 depicts the basic approaches and the applied evaluation criteria, which can be used for the assessment of efficiency of an enterprise's value chain.

Table 1 Approaches and criteria used for the efficiency evaluation of an enterprise's value chain

\begin{tabular}{|l|l|}
\hline \multicolumn{1}{|c|}{$\begin{array}{c}\text { Approaches to the } \\
\text { efficiency evaluation }\end{array}$} & \multicolumn{1}{c|}{ Fundamental criteria for the efficiency evaluation } \\
\hline $\begin{array}{l}\text { 1. Objective approach } \\
\text { (praxeological) }\end{array}$ & $\begin{array}{l}\text { - basic measures of assessment: efficacy, profitableness, economy of activity } \\
\text { - supplementary measures of assessment: simplicity, purity, soundness, precision, reliability }\end{array}$ \\
\hline 2. Economic approach & $\begin{array}{l}\text { - economic effectiveness (profitability, productivity, work output, ROI, NPV, EVA, MVA, } \\
\text { IRR, etc.) influences the results of an enterprise } \\
\text { - level of efficiency of an enterprise's property management } \\
\text { - level of an enterprise's value and its dynamics } \\
\text { - level of costs and their influence on the margin (value added) } \\
\text { - level of results' orientation } \\
\text { - efficacy and effectiveness of the applied measurement systems and results' records }\end{array}$ \\
\hline
\end{tabular}




\begin{tabular}{|c|c|}
\hline $\begin{array}{l}\text { 3. Stakeholders' groups } \\
\text { approach }\end{array}$ & $\begin{array}{l}\text { - degree of identification of various stakeholders' groups expectations } \\
\text { - degree of accomplishment of objectives, with regard to the important stakeholders' groups } \\
\text { - degree of value added realization by an enterprise, with regard to different stakeholders' } \\
\text { groups } \\
\text { - degree of an enterprise's expectations towards different groups of stakeholders } \\
\text { - ability to create and structure business relations }\end{array}$ \\
\hline $\begin{array}{l}\text { 4. Systemic approach } \\
\text { (cybernetic) }\end{array}$ & $\begin{array}{l}\text { - evaluation of the level of inputs } \\
\text { - evaluation of the transformation process } \\
\text { - evaluation of the level of outputs } \\
\text { - ability to acquire resources from the environment } \\
\text { - level of exploitation of the acquired resources } \\
\text { - the system's productivity } \\
\text { - survival and development } \\
\text { - harmony and social cooperation } \\
\text { - balance - variability of the system } \\
\text { - organizational efficiency } \\
\text { - technical efficiency } \\
\text { - economic efficiency } \\
\text { - human efficiency }\end{array}$ \\
\hline 5. Resource approach & $\begin{array}{l}\text { - efficiency of both quantitative and qualitative acquisition of necessary resources and } \\
\text { competences (resources such as financial, human, material, informational and knowledge) } \\
\text { - level of availability and exploitation of resources and competences within the strategy's } \\
\text { realization } \\
\text { - level of development and transformation of resources and competences into products and } \\
\text { services } \\
\text { - level of protection of resources and competences within a company }\end{array}$ \\
\hline 6. Process approach & $\begin{array}{l}\text { - degree of process maturity of an organization } \\
\text { - efficiency of accomplishment of consecutive fundamental and supportive processes } \\
\text { - orientation for: a customer, time, costs, quality } \\
\text { - flexibility/adaptability, dynamics of changes within processes, innovation }\end{array}$ \\
\hline $\begin{array}{l}7 . \quad \text { Subjective-relational } \\
\text { approach }\end{array}$ & $\begin{array}{l}\text { - number of subjects participating in a value chain (complexity of a value chain) } \\
\text { - division of functions (roles) between the subjects of a value chain } \\
\text { - firm's participation in alliances, mergers, takeovers (external development) } \\
\text { - strong bargaining position of subjects from the value chain and changes in the movement } \\
\text { of value added } \\
\text { - value of relations (quality, long-lasting nature, effectiveness) } \\
\text { - level of internal and external communication }\end{array}$ \\
\hline 8. Managerial approach & $\begin{array}{l}\text { - efficiency level of the management system (competences, management style, leadership, } \\
\text { motivation, corporate culture, resourcefulness) } \\
\text { - efficacy and effectiveness level of strategic and operational planning (efficacy, effectiveness } \\
\text { and flexibility of a strategy) } \\
\text { - efficiency of planning (perfecting) of an organization (structure, strategy, technology, } \\
\text { motivation, people, finances) } \\
\text { - efficiency level of an information-decision-making process } \\
\text { - efficacy (effectiveness) level of the motivation system } \\
\text { - effectiveness and speed of changes' implementation } \\
\text { - efficacy and effectiveness level of knowledge management } \\
\text { - efficacy and effectiveness level of risk management } \\
\text { - level of selection and exploitation of resources, management methods } \\
\text { - efficacy and effectiveness level of strategic and operational controls }\end{array}$ \\
\hline
\end{tabular}

Source: own elaboration

The approaches presented above do not constitute an exhaustive list, because within the efficiency evaluation of an organization's functioning, one can also apply other approaches, for instance, technical, ergonomic, functional, behavioral, systemic, holistic (comprehensive), project, diagnostic, prognostic, situational, formalistic, value analysis, structural, etc. Diversity of approaches presented in the literature, shows that, despite the huge importance of efficiency as a criterion for the evaluation of a value chain's functioning, one perfect method of measurement and assessment of this category 
still has not been created and also a full identification of factors influencing it, has not been performed. While creating the new models of efficiency evaluation, researchers try to keep up with the development of theory and practice, with the changing expectations and value systems of societies.

The results of enterprises' activity are most often analyzed from the perspective of two elements: (1) efficiency, connected with the degree of ability to achieve the prescribed objectives by a given company, and (2) effectiveness, understood as a relation between the resources engaged in triggering the specific set of effects, such as accomplishment of a firm's objectives (van Weele, 1994). According to A. Rolstadas, a result of an enterprise's functioning is influenced by three driving forces of a value chain, also known as the fundamental dimensions of business: efficiency (to what degree the needs of clients are satisfied), effectiveness (what is the degree of economical exploitation of a company's resources) and variability (to what extent companies are prepared for future changes) (Rolstadas, 1995). Efficiency can be described within the categories of quality of the processes' results, meaning how efficient company is in meeting the demand. Effectiveness is measured by productivity indicators, sometimes combined with the exploitation indicators. An improvement in the area of efficiency is typically associated with the growth of effectiveness (productivity). Taking into account the market and financial aspects of a business during the measurement processes guarantees the securement of interests of the two fundamental groups of an organization's clients (Kisperska-Moroń, 2006):

1. External and/or internal market clients, having a need for the products or services.

2. Owners and/or shareholders, expecting the financial results to be suitable for the securement of their interests.

In these times, it is then advisable to observe the three driving forces of a value chain - clients' satisfaction, flexibility and productivity - as an integrated system, rather than three interdependent factors. For the purposes of measurement and evaluation of a value chain's efficiency, one can use quantitative and qualitative criteria. Among the criteria, commonly applied for the efficiency assessment of a products' flow along the value chain, one can mention: economic effectiveness, productivity, time needed for a completion of orders, level of customers service, time needed for transport, prompt and reliable deliveries, level of reserves (Ciesielski, 2011). Moreover, one can also distinguish measures of evaluation of a value chain's functioning, such as quality, delivery time, whole cycle time and losses (Kisperska-Moroń, 2006). While assessing the efficiency of a value chain, it is necessary to consider not only the parameters of the obtained value added, but also an impact of the incurred costs on the accomplishment of the prescribed objectives. During the analysis of a value chain's effectiveness, it can be perceived in the aspect of the degree of accomplishment of the planned activities or the adopted objectives. The most crucial category of evaluation of an enterprise's value chain is the value added (profit), which can be calculated with the use of various measures (accounting, financial and market), dividing them into absolute and relative measures (Borowiecki, 2009; Jaki, 2012).

The manner and scope of application of different criteria for the efficiency evaluation of a value chain would depend on the aim and purpose of the obtained results, and also on 
the ability to collect data in order to perform the assessment. These criteria for evaluation of a value chain may be also determined and extended, taking into account assessment of consecutive fundamental processes: logistics, design, production, services' provision, sales, customers' service, together with the supportive and managerial processes: finances, marketing, technology, human resources, infrastructure. Therefore, measurement and evaluation constitute the fundamental issues in creation of efficient value chain of an enterprise and also in decision-making in the sphere of choice of a competitive market strategy.

\section{Conclusion}

Making an appraisal of efficiency of a value chain in different dimensions and on different levels, allows for determining the directions of its further development, not only from the perspective of an enterprise where the analysis is conducted, but also from the point of view of each participant, functioning in the system of a specific value chain, as any enterprise is able to improve the efficiency of its internal and external value chain, and thanks to that, strengthen its competitive advantage.

An efficient value chain is the one that creates the value for all stakeholders and thanks to this, is competitive and contributes to the growth of organizations comprised within. Such a chain is characterized by the speed of responding to the needs of customers, cost effectiveness, reliability and innovation; it is also flexible and adaptable, concentrated primarily on the customer, as well as socially responsible (Shen \& Lapide, 2005; Tarasiewicz, 2014). Efficiency of a value chain may be increased through: optimization of consecutive fundamental and supportive functions of an enterprise, better coordination of fundamental and supportive functions, as well as through better coordination of suppliers and purchasers with the value chain, and in case of strategic alliances, also coordination of competitors (Gierszewska \& Romanowska, 2003).

\section{References}

Aljibouri, S. (2002). Effects of Resource Management Regimes on Project Schedule. International Journal of Project Management, 20: 271-273.

Barczak, B. (2016). Koncepcja oceny efektywności struktur sieciowych, Zeszyty Naukowe, Seria Specjalna: Monografie, No. 241, Uniwersytet Ekonomiczny w Krakowie, Kraków.

Bartusik, B., \& Soltysik, M. (2015). Projektowanie struktur organizacyjnych w perspektywie gospodarki opartej na wiedzy. In A. Stabryła (Ed.), Metodologia projektowania systemów organizacyjnych przedsiębiorstwa (pp. 255-280). Warszawa, Poland: C.H. Beck.

Bielski, M. (1996). Organizacja. Istota, struktura, procesy. Łódź, PL: Wydawnictwo Uniwersytetu Łódzkiego.

Bielski, M. (2002). Podstawy teorii organizacji i zarządzania. Warszawa, PL: Wydawnictwo C.H. Beck.

Blaik, P. (2002). Logistyczno-marketingowy łańcuch tworzenia wartości jako systemowa determinanta efektywności zarzadzania. In J. Witkowski (Ed.), Logistyka przedsiębiorstw w warunkach przemian (pp. 50-58), Wrocław, Poland: Prace Naukowe Akademii Ekonomicznej we Wrocławiu. 
Borowiecki, R. (2009). Pomiar i ocena procesów kreowania wartości w badaniu efektywności przedsiębiorstwa. Kraków, PL: Wydawnictwo Fundacji Uniwersytetu Ekonomicznego w Krakowie.

Bratnicki, M., \& Kulikowska-Pawlak, M. (2013). Uwarunkowania pomiaru efektywności organizacji. Finanse i Zarządzanie, (4): 2-4.

Cabała, P. (2007). Wprowadzenie do prakseologii. Przegląd zasad skutecznego działania. Kraków, PL: Wydawnictwo Akademii Ekonomicznej w Krakowie,.

Cholewicka-Goździk, K. (2001). Zarządzanie jakością - instrument wzrostu wartości firmy. Master of Business Administration, (2).

Chuengsatiansup, K. (2003). Spirituality and health: an initial proposal to incorporate spiritual health in health impact assessment. Environmental Impact Assessment Review, 23(1): 3-15.

Ciesielski, M. (2011), Zarządzanie łańcuchem dostaw. Warszawa, PL: PWE.

Crook, T.R., Ketchen, D.J., Combs, J.G., \& Todd S.Y. (2008). Strategic resources and performance: A meta-analysis, Strategic Management Journal, (29): 1141-1154.

Duraj, J. (2004). Podstawy ekonomiki przedsiębiorstwa. Warszawa, PL: PWE.

Dwojacki, P., Sikorski, Cz., \& Nogalski B. (1999). Zarządzanie w nowych czasach. Przegląd Organizacji, (9):15

Freeman, R.E. (1984). Strategic management. A stakeholder approach. Boston, US: Pitman Publishing.

Gierszewska, G., \& Romanowska, M. (2003). Analiza strategiczna przedsiębiorstwa. Warszawa, PL: PWE.

Grajewski, P. (2007). Organizacja procesowa. Projektowanie i konfiguracja. Warszawa, PL: PWE.

Greve, H.R. (2011). Positional rigidity: Low performance and resource acquisition in large and small firms. Strategic Management Journal, 32 (1): 103-114.

Hendzel, D. (1998). Działanie w teorii zarządzania. In K. Jaremczuk (Ed.), Człowiek w procesie gospodarowania. Rzeszów, Poland: Poligrafia Wyższego Seminarium Duchownego w Rzeszowie.

Henri, J.F. (2004). Performance Measurement and Organizational Effectiveness: Bridging the Gap. Managerial Finance, (6): 93-123.

Holstein-Beck, M. (1987). Szkice o pracy. Warszawa, PL: Książka i Wiedza.

Jabłoński, M., \& Jabłoński, A. (2006). Efektywne modele biznesu. Zeszyty Naukowe Wyższej Szkoły Humanitas w Sosnowcu, (2): 67-75.

Jaki, A. (2012). Mechanizmy procesu zarządzania wartością przedsiębiorstwa. Kraków: UEK w Krakowie.

Janasz, W. (2003). Kształtowanie wartości podmiotu gospodarującego. Przegląd Organizacji, (6): $30-33$

Keeley, M. (1984). Impartiality and participant interest theories of organizational effectiveness. Administrative Science Quarterly, 28:1-23.

Kieżun, W. (1997). Sprawne zarzadzanie organizacją. Zarys teorii i praktyki. Warszawa, PL: SGH.

Krstić, B., \& Krstić, M. (2014). Rational choice theory and random behavior. EkonomikaJournal of Economic Theory and Practice and Social Issues, 61(1): 1-15.

Krstić, B., \& Krstić, M. (2014). Models of irrational behaviour of household and firm. Ekonomika - Journal of Economic Theory and Practice and Social Issues, 61(4): 1-10. 
Kisperska-Moroń, D. (2006). Pomiar funkcjonowania łańcuchów dostaw. Katowice, PL: Wyd. AE.

Kotarbiński, T. (1982). Traktat o dobrej robocie. Wrocław-Warszawa-Kraków, PL: Wydawnictwo Ossolineum.

Lange, O. (1978). Ekonomia polityczna. Warszawa, PL: PWN.

Łasiński, G. (2003). Sprawność zarządzania organizacją sportową. Wrocław, PL: Wydawnictwo Akademii Wychowania Fizycznego we Wrocławiu.

Lichtarski, J. (1999). Cele stakeholders a cele przedsiębiorstwa, [w:] Kategoria wartości a cele przedsiębiorstwa, K. Jaremczuka (red.), Oficyna Wydawnicza Politechniki Rzeszowskiej, Rzeszów.

Machnik, A. (2002). Sekrety sprawnego działania. Warszawa, PL: Wydawnictwo Studio EMKA.

Malik, L. (2004). Efektywność zrównoważonego i trwałego rozwoju w wymiarze lokalnym i regionalnym. Opole. PL: Instytut Śląski Sp. z o.o.

Skorupka, S. H., \& Auderska, Z. (1997). Mały słownik języka polskiego. Warszawa, PL: Łempicka. PWN.

Martyniak, Z. (2000). Efektywność organizacji. Ekonomika i Organizacja Przedsiębiorstwa, (11): 28-33.

Matwiejczuk, R. (2010). Przesłanki tworzenia wartości w łańcuchu wartości. Przegląd Organizacji, (5): 16-19.

Mazurkiewicz, A. (2011). Sprawność działania - interpretacja teoretyczna pojęcia. In M. G. Woźniak (Ed.), Nierówności społeczne a wzrost gospodarczy. Uwarunkowania sprawnego działania w przedsiębiorstwie i regionie (pp. 47-57). Rzeszów, Poland: Zeszyt Naukowy Uniwersytetu Rzeszowskiego.

Nowosielski, S. (2008). Procesy i projekty logiczne. Wrocław, PL: Wydawnictwo Uniwersytetu Ekonomicznego we Wrocławiu.

Nowosielski, S. (2011). Orientacja procesowa w organizacjach. Rozważania nad skutecznością wprowadzania. Prace Naukowe Uniwersytetu Ekonomicznego we Wrocławiu, (169): 93106.

Panfil, R. (2006). Prakseologia gier sportowych, Studia i Monografie Akademii Wychowania Fizycznego we Wrocławiu, (82).

Porter, M.E. (1992). Strategia konkurencji. Metody analizy sektorów i konkurentów. Warszawa, PL: PWE.

Potoczek, N. (2010). System społeczny w organizacji zorientowanej procesowo. In A. Nalepki \& A Ujwary-Gil (Eds.), Organizacje komercyjne i niekomercyjne wobec wzmożonej konkurencji oraz wzrastających wymagań konsumentów (pp. 57-68). Nowy Sącz, Poland: Wyższa Szkoła Biznesu - National-Louis University w Nowym Sączu.

Rollinson, D. (2002). Organisational behaviour and analysis. New Jersey, US: Prentice-Hall.

Rolstadas, A. (1995). Performance Management: A Business Process Benchmarking Approach. London, UK: Chapman \& Hall.

Romanowska, M. (2001). Kształtowanie wartości firmy w oparciu o kapitał intelektualny. In R. Borowiecki \& M. Romanowska (Eds.), System informacji strategicznej (pp. 14-32). Warszawa, PL: Wywiad gospodarczy a konkurencyjność przedsiębiorstwa.

Romanowska, M. (2002). Efektywny nadzór korporacyjny. Warszawa, PL: PWE.

Rummler, G.A., \& Brache, A.P. (2000) Podnoszenie efektywności organizacji. Warszawa, PL: PWE. 
Samuelson, P.A., \& Nordhaus, W.D. (1995). Ekonomia. Warszawa, PL: PWN.

Seethamraju, R. (2012). Business Process Management-A Missing Link in Business Education. Business Process Management Journal, 18(3): 532-547.

Sierpińska, M., \& Jachna, T. (2004). Ocena przedsiębiorstwa według standardów światowych. Warszawa, PL: PWN.

Skrzypek, E. (2000). Jakość i efektywność. Lublin, PL: Wydawnictwo UMCS,.

Skurzyńska-Sikora, U. (2009). Organizacyjne uczenie się a efektywność przedsiębiorstw. In A. Sitko-Lutek, E. Skrzypek (Eds.), Organizacyjne uczenie się w rozwoju kompetencji przedsiębiorstw, Warszawa, Poland: Wydawnictwo C.H. Beck.

Stabell C., \& Fjeldstad, O. (1998). Configuring value for competitive advantage: On chains, shops, and networks. Strategic Management Journal, 19 (5): 413-437.

Stabryła, A. (2006). Zarządzanie projektami ekonomicznymi i organizacyjnymi. Warszawa, PL: Wydawnictwo Naukowe PWN.

Stabryła, A. (2007). Zarządzanie strategiczne w teorii i praktyce firmy. Warszawa-Kraków, PL: WN PWN.

Sudoł, S. (2002). Przedsiębiorstwo. Podstawy nauki o przedsiębiorstwie. Teoria i praktyka zarządzania. Toruń, PL: Dom Organizatora.

Supernat, J. (2005). Zarządzanie. Warszawa, PL: PWE.

Shen, T. (2005). Linking Supply Chain Practices to Operational and Financial Performance. In Larry Lapide (ed). Supply Chain 2020 Project Working paper, MIT Centre for Transportation and Logistics (pp. 21-23), Massachusetts, USA: Massachusetts Institute of Technology.

Szafrański, M. (2003). Skuteczność działania. Problemy Jakości, (3): 23-28.

Szczepańska, K. (2010). Teoria zarzadzania wartością w ujęciu praktyki zarzadzania jakością. Współczesna Ekonomia, 1 (13): 163-173.

Tarasiewicz, R. (2014). Jak mierzyć efektywność łańcuchów dostaw. Warszawa, PL: Oficyna Wydawnicza SGH.

Van Weele, A.J. (1994). Purchasing Management. Analysis, Planning and Practice. London, UK: Chapman \& Hall.

Walas-Trębacz, J. (2015). Projektowanie łańcucha wartości. In A. Stabryła (ed.), Metodologia projektowania systemów organizacyjnych przedsiębiorstwa (pp. 351-387), Warszawa, Poland: C.H. Beck.

Woźniak K., 2012, Miary sprawnego działania [w:] Podstawy organizacji i zarzadzania, A. Stabryła (red.), Uniwersytet Ekonomiczny w Krakowie, Kraków 2012, pp. 98-109

Wysokińska-Senkus, A. (2013). Doskonalenie systemowego zarządzania w kontekście sustainability. Warszawa, PL: Difin.

Ziębicki, B. (2014). Efektywność organizacyjna podmiotów sektora publicznego. Kraków, PL: Wydawnictwo Uniwersytetu Ekonomicznego w Krakowie.

Zieleniewski, J. (1967). Organizacja zespołów ludzkich: wstęp do teorii organizacji i kierowania. Warszawa, PL: PWN. 